\title{
APERITIF
}

In the bar of the Hotel de France

I waste time working up my hopes

My heart flutters like a leaf

Beside the fluttering of a hundred green leaves

Of the girls who forgot you

You could recollect one of them

Who was a wild apple

Hardly touched by the first frost

But the aperitif is delicate

Like a linnet on a strand of barbed wire

Like the smell of earth after watering

Like the tired light of a bicycle

In the road where the postman's lost his way

Tipsy like me in the middle of the day.

\section{Nobody's Died Yet IN This House}

Nobody's died yet in this house.

The walnut tree's omens

aren't yet deciphered

and returning footsteps

are always ones we know.

Nobody's died yet in this house.

That's what the heavy heads of roses think,

where the do-nothing dew swings

while the worm curls like a threat

in the vineyards' sterile talons.

Nobody's died yet in this house.

No hand seeks an absent hand.

The fire doesn't yet yearn for the one

who took care to light it.

Night hasn't collected its powers. 
Nobody's died but everybody has.

Unknown faces show up in the mirrors

others drive our cars to other towns.

I look at an orchard whose fruits I remember.

We hear only the usual footsteps.

Fire teaches the children its tongue

dew amuses itself swinging in the roses.

Nobody's died yet in this house.

\section{THE KeY}

Hand over the key to autumn.

Tell it of the mute river on whose bottom

lies the shadow of wooden bridges

vanished years ago.

You haven't told me any of your secrets.

But your hand is the key that opens the door of the ruined mill where my life sleeps

between dust and more dust, ghosts of winters, the wind's horsemen dressed in mourning who flee after stealing bells in the poor villages.

But my days will be clouds to travel through the springtime of your sky.

We'll go out in silence, without waking up the time.

I'll tell you we could be happy. 